\title{
The relationship between hypoxia, inflammation, and airway obstruction with carotid intima-media thickness in Chronic Obstructive Pulmonary Disease (COPD)
}

\section{Kronik Obstrükktif Akciğer Hastalığ॥ (KOAH)" da karotis intima-media kalınlığı ile inflamasyon, hipoksi ve hava yolu obstrüksiyonu arasındaki ilişki}

\author{
Neslihan Taş ${ }^{1}$, Sullhattim Arslan², Güilhan Koşucư ${ }^{3}$, Güllay Çetin ${ }^{4}$
}

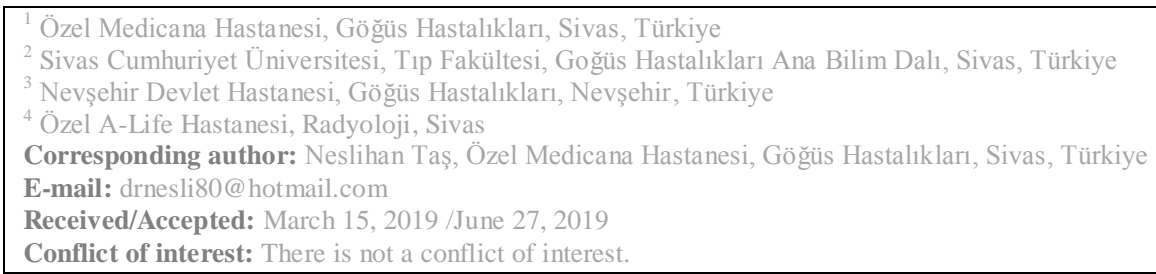

\section{SUMMARY}

The present study aimed to determine whether there is a relationship between intima-media thickness (IMT) changes in peripheral vessels (carotid and vertebral artery) and inflammatory mediators (C-reactive protein (CRP), leucocytes, etc.), artery blood gas changes and airway obstruction in COPD patients. This study included 60 patients with COPD and 40 healthy control subjects. We used the GOLD criteria for COPD diagnosis. The patient group differentiated according to arterial blood gas values and the presence or absence of pulmonary failure, and its type if any was present. In all patients and control group members, blood leucocytes and CRP values were measured. The carotid, vertebral artery thickness, and total cerebral blood flow were measured using a Doppler USG device and standardized $7 \mathrm{MHz}$ linear transducers. There was no significant relationship between age, sex, body mass index (BMI) and intima-media thickness between the two groups. In the present study, we found out that the CRP levels were higher in COPD patients than in the control group. In progressive COPD patients, CRP levels were the highest. Furthermore, we found out the CIMT was higher in COPD patients compared to the control group.

In conclusion, the CIMT and atherosclerosis risk increased in COPD patients. Systemic inflammation causes a higher carotid intima-media thickness in COPD patients. This finding was used as an early risk factor for cardiovascular disease. Doppler USG was used to identify a carotid artery pathology early. Systematic inflammation continuing during a stable period causes increased carotid artery intima-media thickness. This entity plays a role in atherosclerosis etiology.

Keywords: COPD, inflammation, hypoxia, obstruction, atherosclerosis
Neslihan Taş
Sulhattin Arslan
D Gülhan Koşucu
iD Gülay Çetin

ORCID IDs of the authors: N.T. 0000-0002-8905-1896 S.A. 0000-0002-3744-6175 G.K.0000-0003-2881-9360 G.C..0000-0002-0928-8827 


\section{ÖZET}

Çalışmamızın amacı; periferik damarlarda (karotis ve vertebral arter gibi) oluşan intima-media kalınlığı (IMK) değişiklikleri ile KOAH’ta inflamatuar proçesi gösteren mediyatörler (C-reaktif protein (CRP), lökosit, gibi), arter kan gazı değiş̧iklikleri ve oluşan hava yolu obstrüksiyonu arasında ilişki olup olmadığını değerlendirmekti. Bu çalışmaya 60 KOAH hastası, 40 sağlıklı gönüllü alındı. KOAH tanısı GOLD kriterlerine göre kondu. Hasta grubu arter kan gazı (AKG) değerlerine göre solunum yetmezliği olup olmamasına ve varsa tipine göre ayrıldı. Tüm hasta ve sağlıklı kontrol grubunda bulunan kişilerin, periferik kan lökosit, CRP düzeyleri ölçüldü, Doppler Ultrasonografi cihazı ve standart 7 $\mathrm{MHz}$ lineer transdüser kullanılarak karotis, vertebral arterler ve total serebral kan akımları değerlendirildi. Çalışmamızda yaş, cinsiyet, VKİ ve İMK arasında anlamlı ilişkiye rastlanmadı. Hasta grubunda, kontrol grubuna göre CRP değerleri yüksek bulundu. Hastalarda, sağlıklı bireylere göre karotis intima media kalınlığı artmıştı. Hipoksik hastalarda intima media kalınlığı anlamlı oranda yüksek bulundu.

Sonuç olarak, KOAH'ta sistemik inflamasyon ve bunun sonucu olarak artmış karotis arter İMK'nın saptanması serebrovasküler hastalık riski açısından erken bulgu olarak kabul edilebilir. Stabil dönemde devam eden sistemik inflamasyonun karotis arter İMK'da artışa yol açabileceği ve dolayısıyla aterosklerozun etiyolojisinde rol oynayabileceği sonucuna varıldı.

Anahtar sözcükler: KOAH, inflamasyon, hipoksi, obstrüksiyon, ateroskleroz

\section{INTRODUCTION}

Chronic obstructive pulmonary disease is a systemic inflammatory disease, which is characterized by progressive and not fully reversible airflow limitation, and which develops with the abnormal inflammatory response to harmful particles and gases. The role of chronic inflammation in the pathogenesis of the chronic obstructive pulmonary disease (COPD) is a significant ${ }^{1,2}$. This systemic inflammation may cause pathology in both the lungs and other systems. The results of the studies suggest that COPD is a risk factor for cardiovascular disease ${ }^{3}$. The increased cardiovascular risk appears to be parallel with the decrease in FEV1 ${ }^{3}$. However, the clinical outcomes of this are not fully known. Besides, the role of other factors associated with inflammation or hypoxia is not clear. Carotid intima-media thickening (IMT), which is a useful marker for early atherosclerosis, has been suggested to be used for the early period evaluation of cardiovascular risk ${ }^{4}$. Systemic inflammation and hypoxemia are occurring in COPD cause systemic vascular responses by leading to the thickening of the large vessel walls, destruction of the arterial wall, pulmonary hypertension, and cor pulmonale. This study aimed to investigate whether there is a relationship between IMT changes occurring in peripheral vessels (such as the carotid and vertebral artery) and inflammatory mediators (such as CRP, leukocytes), arterial blood gas changes, and airway obstruction in COPD patients.

\section{GENERAL INFORMATION}

Chronic obstructive pulmonary disease (COPD) is a disease characterized by progressive airflow limitation that is not fully reversible. This disease develops as a result of an inflammatory process which occurs against harmful gases and particles, especially cigarette smoke. Inflammation is not limited only to the lungs but also displays systemic characteristics 5 . Pathological changes depend on inflammatory cell infiltration, chronic inflammation caused by this infiltration, and structural changes caused by improper functioning of repair mechanisms ${ }^{6}$.

It is thought that systemic inflammation plays a role in the pathogenesis of cardiovascular disease and atherosclerosis in COPD patients. Chronic low-grade systemic inflammation is thought to be one of the most key events leading to plaque formation. The leukocyte adhesion required for atheroma plaque formation is prevented by normal endothelial function under physiological conditions. However, in cases of chronic systemic inflammation (such as diabetes, COPD, or obesity), the endothelium starts to express excessively surface adhesion molecules, such as VCAM-1, allowing leukocytes in the circulation to adhere to damaged endothelial surfaces. The inflammatory reaction series is triggered by the adhesion of leukocytes to the endothelial surface ${ }^{7}$. Some molecules may promote or increase this inflammatory process. The most investigated of these molecules is CRP.

C-reactive protein is an acute phase protein, which is mostly synthesized in response to tissue damage and/or inflammation. Its release occurs mainly in the liver from the tissue with inflammation. Since there is chronic inflammation in COPD patients and COPD causes the increase in the release of IL-6, which is one of the major mediators of inflammation, an increase occurs in CRP levels. For this reason, $\mathrm{CRP}$ is used as an inflammatory marker 
${ }^{8,9}$. Although it has been demonstrated in crosssectional studies that CRP has a relationship with $\mathrm{FEV}_{1}$, it has been shown in longitudinal studies that it has no relation with the progressive decrease in $\mathrm{FEV}_{1}{ }_{1}$.

COPD is one of the major causes of chronic respiratory failure. As the disease progresses, ventilation/perfusion imbalance, a decrease in diffusion capacity, and hypoxemia due to alveolar hypoventilation develop. Especially during the attack period of the disease, hypoxemia becomes even more profound. In the case of the decrease of the partial oxygen pressure $\left(\mathrm{PaO}_{2}\right)$ in the arterial blood below 60 $\mathrm{mmHg}$, tissue hypoxia occurs, and this causes significant systemic effects ${ }^{11}$.

The brain's nutrition is provided by four major arterial roots: two internal carotid arteries (ICA) and two vertebral arteries (VA), which originate from the arcus aorta. The brain, which receives $750 \mathrm{ml}$ of blood per minute, provides $500 \mathrm{ml}$ of this blood from the carotid system and $250 \mathrm{ml}$ from the vertebrobasilar system. Cerebral blood flow (CBF) is normally 40-60 ml/100 $\mathrm{g}$ brain tissue/minute on averag ${ }^{\mathrm{e}}{ }^{12}$.

In society, the average values of IMT change between $0.4-1.0 \mathrm{~mm}$, and an annual increase of 0.01-0.03 $\mathrm{mm}$ occurs. According to some studies, IMT more than $1.2 \mathrm{~mm}$ thick is considered abnormal. The increase in this thickness is the earliest indication of atherosclerotic diseases. The intima-media thickness is associated with cardiovascular risk factors. The increase in the intima-media thickness increases the risk of developing vascular symptoms in asymptomatic patients 13,14 .

\section{MATERIAL AND METHODS}

This study is a cross-sectional observational study. For the study, permission was obtained from the Ethics Committee of the Faculty of Medicine of Cumhuriyet University with the decision numbered 2010-01/43.

A total of 100 people, 60 patients with COPD who applied to Cumhuriyet University Faculty of Medicine Department of Chest Diseases and did not have any systemic disease such as hypertension, coronary artery disease, "obstructive sleep apnea syndrome", diabetes mellitus, congestive heart failure, renal failure, hyperlipidemia, hypercholesterolemia, etc. and 40 healthy individuals, were included in the study.
While the oxygen percentage $\left(\mathrm{FiO}_{2}\right)$ of the inhaled air for ABG analysis was $21 \%$ (in room air), $2 \mathrm{ml}$ of blood was collected from the radial artery to the heparinized injector. Thirty minutes before the arterial blood was collected, oxygen receiving of the patients had been given a break. Arterial blood gases analysis was performed using a blood gas analyzer (Beckman Coulter device). In $\mathrm{ABG}$ evaluations, $\mathrm{pH}<7.35$ was considered acidosis, and $\mathrm{pH}>7.45$ was considered alkalosis. $\mathrm{PaCO}_{2}$ was evaluated as hypercapnia if it was greater than $45 \mathrm{mmHg}$, and as hypocapnia, if it was lower than $35 \mathrm{mmHg}$. In terms of oxygenation, $\mathrm{PaO}_{2} \leq 55 \mathrm{mmHg}$ and/or $\mathrm{SaO}_{2} \leq, 88 \%$ values were considered as hypoxemic respiratory failure criteria. The obtained $A B G$ results were recorded.

Respiratory function tests (RFT), $\left(\mathrm{FEV}_{1}, \mathrm{FVC}\right)$ measurements were performed by a dry type standard spirometer (Vimax 20C, Sensormedics229-Netherlands) device. According to RFT results, the GOLD (Global Initiative for Chronic Obstructive Lung Disease) criteria were used for the diagnosis of COPD (4). For the diagnosis, the $\mathrm{FEV}_{1} / \mathrm{FVC}$ ratio, measured at least $15-20$ minutes later after administering $400 \mathrm{mcg}$ salbutamol or $1000 \mathrm{mcg}$ terbutaline, was required to be less than $70 \%$.

The consent of all patients and all healthy individuals in the control group was received, and their blood leucocyte (Advia, Germany) and C-reactive protein (Beckman-Coulter, USA) levels were measured. Their carotid artery IMTs were measured by using a Doppler ultrasonography device (General Electric LOGIQ 9, USA) and a standard $7 \mathrm{MHz}$ linear transducer in the Department of Radiology of the Faculty of Medicine of Cumhuriyet University.

Since healthy individuals who did not smoke were included in the study as the control group, $\mathrm{ABG}$ and RFT were not studied.

In all cases included in the study, carotid and vertebral artery Doppler ultrasonographic examinations were performed in the Ultrasonography unit of the Radiology Department of Cumhuriyet University Faculty of Medicine. In order to avoid inter-observer measurement differences, all measurements were performed by one radiologist using the same device and transducer (General Electrics, Logiq 9, 9-14 MHz matrix linear transducer).

Examination of each case was started after 15 minutes of resting in the supine position. The 
head was turned around $10^{\circ}$ in the carotid artery measurements and about $25-40^{\circ}$ in the opposite direction in the VA measurements. On both sides, the examination was started just above the clavicles and the common carotid artery (CCA), internal carotid artery (ICA), external carotid artery (ECA), and vertebral arteries (VA) were examined by moving the transducer in the cranial direction. The examination was started with a real-time grey scale, and the axial and sagittal examination was carried out, then the PDU examination was performed, and finally, spectral measurements were taken. In order to take measurements without error, the diameters of the vessels were obtained by measuring the distance between the two echogenic intimae as perpendicular to the lumen upon the magnified B-mode images obtained at the end of the diastole. The posterior wall measurement was independent of the gain setting, and due to the higher histology correlation with sonography, the measurements were made from the posterior wall. Then Color Doppler Ultrasonography (CDU) was examined, and the presence of flow in the vein and possible isoechogenic plaques were investigated. The total brain blood flow volume was calculated by collecting bilateral ICA and VA blood flow volumes.

The data of the study were uploaded to SPSS 14.0 (Statistical Package for Social Sciences) package program. In the evaluation of the data, besides descriptive statistical methods (mean, standard deviation), in the comparison of quantitative data, Student's t, Mann-Whitney U, Fisher's test and chi-square tests were used in the intergroup comparisons of the parameters that were not normally distributed. Pearson's correlation test was used in the correlation analysis. The p-value smaller than 0.05 was considered as statistically significant. Data were presented as arithmetic mean (X), standard deviation (SD), number of individuals (n), and percentage $(\%)$ in the tables.

\section{RESULTS}

In this study, 60 patients with COPD and 40 healthy adults were examined to evaluate whether there was a relationship between the carotid intima-media thickness and inflammatory mediators (such as CRP, leukocytes), hypoxia and airway obstruction in COPD patients.

In the patient group, $38(63.3 \%)$ of 60 patients were male, $22(36.7 \%)$ were female, and in the control group, $20(50 \%)$ were male, and 20 $(50 \%)$ were female. The mean age of the patient group was $61.5 \pm 7.9$ years, and it was $59.5 \pm$ 8.0 years in the control group. $36 \%$ of the patients had a history of smoking. Since the control group consisted of non-smoker healthy individuals, a comparison could not be made.

No significant difference was determined between the patient and control groups in terms of gender, age, and BMI.

When the CRP values of the patient and control groups were compared, the CRP value of the patient group was statistically significantly higher $(\mathrm{p}<0.05)$. There was no significant increase in the leucocyte level.

When the patient and control groups' CCA-ICA intima-media thicknesses were compared, the intima-media thickness of the patient group increased statistically significantly compared to the healthy individuals $(\mathrm{p}<0.05)$ (Table 4.1).

When the relationship between age and the intima-media thickness in the patients was examined, a statistically significant increase in the left ICA intima-media thickness ( $p<0.048$ ) was determined. No statistically significant difference was found between the other parameters ( $p>0.05$ ) (Table 4.2).

When the relation between the gender and intima-media thicknesses in the patients was examined, no statistically significant difference between the two groups was found ( $p>0.005)$.

In the patients, there was no statistically significant increase in the relationship between the body mass index (BMI) and intima-media thickness ( $p>0.05)$

CRP values were found to be significantly higher in the stage 3-4 COPD group in comparison with the stage 1-2 COPD group ( $p$ $<0.05)$.

When the relation between CRP as a marker of inflammation and IMT was examined in the patients, there was a significant difference in terms of the right ICA $(\mathrm{p}<0.025)$ (Table 4.3).

When the relation between hypoxia level and CCA and ICA intima-media thickness in the patients was evaluated, the intima-media thickness was found to be statistically significantly increased as the hypoxia level increased $\left(\mathrm{PaO}_{2}<60 \mathrm{mmHg}\right)(\mathrm{p}<0.05)$ (Table 4.3).

When the relation between the light and severe COPD groups and intima-media thicknesses was examined, the intima-media thicknesses were found to be statistically significantly increased 
in the stage 3-4 COPD group compared to the stage 1-2 COPD group ( $\mathrm{p}<0.05)$ (Table 4.3).

In the multiple regression analysis performed between the carotid intima-media thickness and $\% \mathrm{FEV} 1, \mathrm{PaO}_{2}$ and CRP, a strong correlation was found, especially between the decrease in $\mathrm{FEV}_{1}(\%)$ and the increase in the intima-media thickness ( $\mathrm{p}<0.05)$ (Table 4.4).

In the multiple correlation analysis performed in order to determine the parameter affecting the carotid intima-media thickness, there was a strong correlation, especially between the decrease in $\% \mathrm{FEV}_{1}$ and the increase in the intima-media thickness ( $p<0.05$ ). Likewise, there was a negative correlation between the decrease in $\mathrm{PaO}_{2}$ and the increase in the intimamedia thickness, but it was not as strong as the decrease in \% $\mathrm{FEV}_{1}$ (Table 4.5).

In the multiple regression analysis performed between the carotid intima-media thickness and $\% \mathrm{FEV} 1, \mathrm{PaO}_{2}$ and CRP, a strong correlation was found, especially between the decrease in $\mathrm{FEV}_{1}(\%)$ and increased intima-media thickness $(\mathrm{p}<0.05)$ (Table 4.5).

Table 4.1: Comparison of the Intima-Media Thickness between the Patient and Control Groups

\begin{tabular}{|c|c|c|c|c|}
\hline \multirow{2}{*}{ Group (n) } & \multicolumn{4}{|c|}{ Intima-Media Thickness (mm) } \\
\cline { 2 - 5 } & \multicolumn{3}{|c|}{ CCA } & \multicolumn{2}{c|}{ ICA } \\
\cline { 2 - 5 } & $\begin{array}{c}\text { Right } \\
\left(\mathrm{X}^{*} \mathrm{SD}^{* *}\right)\end{array}$ & $\begin{array}{c}\text { Left } \\
\left(\mathrm{X}^{*} \pm \mathrm{SD}^{* *}\right)\end{array}$ & $\begin{array}{c}\text { Right } \\
\left(\mathrm{X}^{*} \pm \mathrm{SD}^{* *}\right)\end{array}$ & $\begin{array}{c}\text { Left } \\
\left(\mathrm{X}^{*} \pm \mathrm{SD}^{* *}\right)\end{array}$ \\
\hline Patient (n:60) & $0.78 \pm 0.02$ & $0.79 \pm 0.01$ & $0.63 \pm 0.01$ & $0.62 \pm 0.01$ \\
\hline Control (n:40) & $0.71 \pm 0.01$ & $0.71 \pm 0.01$ & $0.55 \pm 0.01$ & $0.57 \pm 0.01$ \\
\hline $\mathbf{p}^{*}$ & 0.035 & 0.003 & 0.001 & 0.021 \\
\hline $\begin{array}{l}\text { CCA: Common carotid artery, ICA: Internal carotid artery, } \mathrm{p}^{*}<0.05 \text { was considered significant, } \\
\mathrm{X}^{*} \text { : Arithmetic mean, SD**: Standard deviation }\end{array}$ \\
\hline
\end{tabular}

Table 4.2: Intima-Media Thicknesses by Age in Patients

\begin{tabular}{|c|c|c|c|c|}
\hline \multirow{3}{*}{$\begin{array}{c}\text { Patient group }(\mathrm{n}=60) \\
\text { Age/year }\end{array}$} & \multicolumn{4}{|c|}{ Intima-Media Thickness (mm) } \\
\hline & \multicolumn{2}{|c|}{$\mathrm{CCA}$} & \multicolumn{2}{|c|}{ ICA } \\
\hline & $\begin{array}{c}\text { Right } \\
\left(\mathrm{X}^{* \pm} \mathrm{SD}^{* *}\right)\end{array}$ & $\begin{array}{c}\text { Left } \\
\left(\mathrm{X}^{*} \pm \mathrm{SD}^{* *}\right)\end{array}$ & $\begin{array}{c}\text { Right } \\
\left(\mathrm{X}^{* \pm} \mathrm{SD}^{* *}\right)\end{array}$ & $\begin{array}{c}\text { Left } \\
\left(\mathrm{X}^{*} \pm \mathrm{SD}^{* *}\right)\end{array}$ \\
\hline$<65$ years $(n: 34)$ & $0.75 \pm 0.32$ & $0.80 \pm 0.22$ & $0.62 \pm 0.18$ & $0.59 \pm 0.16$ \\
\hline$\geq 65$ years $(n: 26)$ & $0.81 \pm 0.29$ & $0.81 \pm 0.24$ & $0.65 \pm 0.19$ & $0.66 \pm 0.23$ \\
\hline $\mathbf{p}^{*}$ & 0.265 & 0.482 & 0.350 & 0.048 \\
\hline
\end{tabular}


Table 4.3: The Relationship Between Hypoxia Level , CRP, Light and Severe COPD Groups, CCA and ICA Intima-Media Thickness

\begin{tabular}{|c|c|c|c|c|}
\hline \multirow{3}{*}{$\begin{array}{l}\text { Patient group }(\mathrm{n}=60) \\
\mathbf{C R P}(\mathbf{m g} / \mathbf{L})\end{array}$} & \multicolumn{4}{|c|}{ Intima-Media Thickness } \\
\hline & \multicolumn{2}{|c|}{$\mathrm{CCA}$} & \multicolumn{2}{|c|}{ ICA } \\
\hline & $\begin{array}{c}\text { Right } \\
\left(\mathrm{X}^{*} \pm \mathrm{SD}^{* *}\right)\end{array}$ & $\begin{array}{c}\text { Left } \\
\left(\mathrm{X}^{*} \pm \mathrm{SD}^{* *}\right)\end{array}$ & $\begin{array}{c}\text { Right } \\
\left(\mathrm{X}^{*} \pm \mathrm{SD}^{* *}\right)\end{array}$ & $\begin{array}{c}\text { Left } \\
\left(\mathrm{X}^{*} \pm \mathrm{SD}^{* *}\right)\end{array}$ \\
\hline CRP(mg/L) 0-8 (n:32) & $0.75 \pm 0.03$ & $0.77 \pm 0.02$ & $0.61 \pm 0.01$ & $0.62 \pm 0.02$ \\
\hline$\geq 8.1(\mathrm{n}: 28)$ & $0.80 \pm 0.02$ & $0.82 \pm 0.02$ & $0.67 \pm 0.01$ & $0.62 \pm 0.01$ \\
\hline $\mathbf{p}^{*}$ & 0.247 & 0.181 & 0.025 & 0.448 \\
\hline $\mathrm{PaO}_{2} \geq(60 \mathrm{mmHg}) \quad(\mathrm{n}: 21)$ & $0.69 \pm 0.02$ & $0.71 \pm 0.02$ & $0.56 \pm 0.01$ & $0.57 \pm 0.01$ \\
\hline 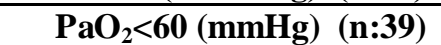 & $0.82 \pm 0.03$ & $0.83 \pm 0.01$ & $0.68 \pm 0.01$ & $0.65 \pm 0.01$ \\
\hline $\mathbf{p}^{*}$ & 0.001 & 0.001 & 0.0001 & 0.004 \\
\hline COPD Stage1-2(n:24) & $0.70 \pm 0.02$ & $0.70 \pm 0.01$ & $0.56 \pm 0.01$ & $0.55 \pm 0.01$ \\
\hline Stage 3-4 (n:36) & $0.82 \pm 0.03$ & $0.85 \pm 0.01$ & $0.68 \pm 0.01$ & $0.67 \pm 0.01$ \\
\hline $\mathbf{p}^{*}$ & 0.001 & 0.0001 & 0.0001 & 0.0001 \\
\hline \multicolumn{5}{|c|}{$\begin{array}{l}\text { CRP: C-reactive protein, CCA: Common carotid artery, ICA: Internal carotid artery, } \mathrm{PaO}_{2} \text { : Partial arterial oxygen } \\
\text { pressure, COPD: Chronic Obstructive Pulmonary Disease } \mathrm{p}^{*}<0.05 \text { was considered significant, } \mathrm{X}^{*} \text { : Arithmetic } \\
\text { mean, } \mathrm{SD}^{* *}: \text { Standard deviation }\end{array}$} \\
\hline
\end{tabular}

Table 4.4: Multiple Regression Analysis Carried out Between Carotid Intima-Media Thicknesses and $\mathrm{FEV}_{1}(\%), \mathrm{PaO}_{2}$, and CRP

\begin{tabular}{|c|c|c|c|c|c|}
\hline Patient n:6 & & Right CCA & Left CCA & Right ICA & Left ICA \\
\hline $\mathrm{FEV}_{1}(\%)$ & $\begin{array}{l}\boldsymbol{\beta} \\
\mathbf{t} \\
\mathbf{p}^{*}\end{array}$ & $\begin{array}{c}-.373 \\
-2.265 \\
.027 \\
\end{array}$ & $\begin{array}{c}-.497 \\
-3.252 \\
.002 \\
\end{array}$ & $\begin{array}{c}-.452 \\
-3.186 \\
.002 \\
\end{array}$ & $\begin{array}{c}.545 \\
-3.402 \\
.001 \\
\end{array}$ \\
\hline $\mathrm{PaO}_{2}$ & $\begin{array}{l}\boldsymbol{\beta} \\
\mathbf{t} \\
\mathbf{p}^{*}\end{array}$ & $\begin{array}{l}-.126 \\
-.745 \\
.459\end{array}$ & $\begin{array}{l}-.148 \\
-.941 \\
.351\end{array}$ & $\begin{array}{c}-.204 \\
-1.399 \\
.167\end{array}$ & $\begin{array}{l}-.027 \\
.162 \\
.872\end{array}$ \\
\hline 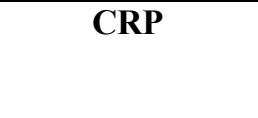 & $\begin{array}{l}\boldsymbol{\beta} \\
\mathbf{t} \\
\mathbf{p}^{*}\end{array}$ & $\begin{array}{l}-.025 \\
-.194 \\
.847\end{array}$ & $\begin{array}{c}-.150 \\
-1.233 \\
.223\end{array}$ & $\begin{array}{l}.077 \\
.681 \\
.499\end{array}$ & $\begin{array}{l}-.082 \\
-.643 \\
.523\end{array}$ \\
\hline
\end{tabular}


Table 4.5: Pearson's Correlation Analysis Carried out Between Carotid Intima-Media Thicknesses and \% $\mathrm{FEV}_{1}, \mathrm{PaO}_{2}$, and CRP

\begin{tabular}{|c|c|c|c|}
\hline Group (n) Patient (n:60) & $\% \mathrm{FEV}_{1}$ & $\mathrm{PaO}_{2}$ & CRP \\
\hline \multicolumn{4}{|l|}{ Right CCA-IMT } \\
\hline $\begin{array}{l}\text { Pearson's Correlation } \\
\end{array}$ & -.451 & -.373 & .140 \\
\hline $\mathbf{p}^{*}$ & 0.001 & 0.003 & 0.166 \\
\hline \multicolumn{4}{|l|}{ Left CCA-IMT } \\
\hline Pearson's Correlation & -.546 & -.428 & .456 \\
\hline $\mathbf{p}^{*}$ & 0.001 & 0.001 & 0.075 \\
\hline \multicolumn{4}{|l|}{ Right ICA-IMT } \\
\hline Pearson's Correlation & -.619 & -.415 & .281 \\
\hline $\mathbf{p}^{*}$ & 0.001 & 0.001 & 0.005 \\
\hline \multicolumn{4}{|l|}{$\begin{array}{l}\text { Left ICA-IMT } \\
\end{array}$} \\
\hline Pearson's Correlation & +.497 & -.315 & .164 \\
\hline $\mathbf{p}^{*}$ & 0.001 & 0.014 & 0.104 \\
\hline $\begin{array}{l}\text { CCA: Common carotid a } \\
\text { Forced expiratory volume } \\
\text { protein, } \mathbf{p}^{*}<0.05 \text { was con }\end{array}$ & : Intern & $\begin{array}{l}\text { IT: In } \\
\text { erial o }\end{array}$ & $\begin{array}{l}\text { s, } \mathrm{FEV}_{1}(\%) \text { : } \\
\text { : C-reactive }\end{array}$ \\
\hline
\end{tabular}

\section{DISCUSSION}

COPD is a multicomponent disease in which structural and functional changes in the lungs and other organs than the lungs are observed. Therefore, the systemic response of COPD patients should be definitely considered. The previous studies have demonstrated that inflammatory mediators, such as CRP and leukocytes, increase both in exacerbations and during a stable period, and systemic inflammation also continues in the stable period ${ }^{15,16}$. In the present study, in order to evaluate the vascular effects of the inflammatory process in COPD patients, the effects of inflammatory markers, especially CRP, hypoxia and airway obstruction (FEV1 \%) on the carotid artery intima-media thickness were investigated in stable period COPD patients.

The most critical changes in the early subclinical period of atherosclerotic disease are endothelial dysfunction observed in all arterial beds and the increase in the intima-media thickness. The combined thickness of the carotid artery intima and media is associated with the prevalence of cardiovascular diseases ${ }^{17}$. Therefore, the intimamedia thickness of the carotid artery, of which increase is determined by non-invasive methods, has predicted the presence or absence of coronary artery disease in many studies ${ }^{18}$.

In the present study, there was no statistically significant difference between the patient and control groups in terms of age, gender, and BMI. COPD and vascular diseases are diseases of advanced age, and as age progresses, their coexistence may be concerned ${ }^{19}$. In the study carried out by Iwamoto et al. on patients with COPD, the carotid intima-media thickness was found to increase with increasing age ${ }^{21}$. In the study in which Ma et al. investigated the intimamedia thickness in 2402 asymptomatic individuals, age was found to be an independent risk factor in the increase of the intima-media thickness ${ }^{20}$. In the study which was carried out by Tosetto et al. with 2513 cases, the intima-media thickness increased with increasing age ${ }^{21}$. In the present study, in patients over the age of 65 years, the intima-media thickness increased, but an increase in the intima-media thickness was determined only in the left ICA, and there was no statistically significant difference in other measurements. 
In the study carried out by Youn et al. on 433 individuals between 40-70 years of age, they determined that the carotid intima-media thickness displayed a correlation with male gender in healthy individuals ${ }^{22}$. Again, in the study by Ma et al., the carotid intima-media thickness was stated to be higher in males than in females ${ }^{20}$. In the present study, although the intima-media thickness increased in males, the difference was not statistically significant.

In many studies conducted, it was found out that CRP increased in COPD patients, and this increase was proportional to airway obstruction in COPD ${ }^{23,25}$. In an 8 -year survey carried out by Ridker et al. on 28000 individuals, the level of CRP was found to be a stronger indicator of myocardial infarction, ischemic stroke, coronary disease, cardiovascular disease deaths compared to LDL cholesterol ${ }^{23}$. Torres et al. investigated the relationship between CRP levels and pulmonary function, arterial oxygen pressure, 6minute walk test, BMI, and smoking in 130 stable COPD patients and 65 healthy nonsmokers in the control group. CRP levels were found to be higher in the COPD group compared to the control group. They demonstrated that there was an inversely proportional change between CRP and FEV1, FEV1\% in stable COPD patients ${ }^{8}$. In the present study, a significant relationship was also found between CRP and FEV1\% ( $p<0.05$ ). Furthermore, in this study, the CRP level was found to be higher in the COPD group compared to the control group.

In a study conducted by Thorleifsson et al. with patients who participated in the BOLD study in Iceland, serum CRP and IL-6 were demonstrated to be closely related to low FEV 1 and FVC (26). In accordance with previous studies, a statistically significant increase was determined in CRP, and leukocyte counts as the COPD stage progressed in our study $(\mathbf{p}<\mathbf{0 . 0 5})$.

In the present study, the intima-media thickness was found to increase as the hypoxia level increased $\left(\mathrm{PaO}_{2}<60 \mathrm{mmHg}\right)(\mathrm{p}<0.05)$. In the correlation analysis, there was a strong correlation between the decrease in $\mathrm{PaO}_{2}$ and the increase in the intima-media thickness. These results confirm the effect of hypoxia on IMT, in accordance with the literature.

The data obtained from 6629 patients, who were involved in the NHANES III study, were examined in order to determine whether there are markers of systemic inflammation including CRP in COPD patients and to investigate the possible connections with cardiovascular damage. Patients with severe to very severe COPD were found to have significantly higher serum leukocyte, platelet, and fibrinogen levels than those without airway obstruction. Although smaller, significant increases were also observed in these inflammation markers in patients with moderate COPD, this indicates that systemic inflammation was associated not only with severe COPD ${ }^{24}$.

\section{CONCLUSION}

In the present study, a significant increase was determined in the intima-media thickness in patients with COPD. No significant relationship was found between the increase in IMT and age, gender, and BMI in COPD patients. There was a significant relationship between CRP increase and IMT only in the right ICA, but this relationship was not significant in the correlation analysis. A significant relationship was determined between obstruction (\%FEV1) in COPD and IMT. This relationship was confirmed by correlation and regression analysis. A significant relation was determined between hypoxia and IMT, and this relation was confirmed by correlation analysis, but a significant correlation was not found in regression analysis. In the present study, the intima-media thicknesses were determined to increase statistically significantly in the Stage 3-4 COPD group in comparison with the Stage 1-2 COPD group ( $\mathrm{p}<0.05)$. In the present study, significantly high IMT and serum CRP level in patients with COPD compared to the control group emphasize the close relationship between COPD, cardiovascular, and cerebrovascular diseases.

\section{REFERENCES}

1- Bartu Saryal S, Acıcan T. (eds) Epidemiyoloji ve risk faktörleri. In: Güncel Bilgiler Işığında KOAH [Epidemiology and risk factors. In: COPD in the light of current information], Bilimsel T1p Kitabevi, Ankara 12-32, 2003.

2- Pauwels RA, Buist AS, Calverley PM, et al. Global strategy for the diagnosis, management, and prevention of chronic obstructive pulmonary disease: NHLBI/WHO Global Initiative for chronic obstructive lung disease (GOLD) Workshop summary. Am J Respir Crit Care Med, 163:1256 -1276, 2001

3- Sin DD, Man SF. Chronic obstructive pulmonary disease as a risk factor for cardiovascular morbidity and mortality. Proc. Am. Thorac. Soc, 2: 8-11, 2005 
4- O'Leary DH, Polak JF. Intima-media thickness: a tool for atherosclerosis. Am. J. Cardiol, 90:1821, 2002.

5- Fabri LM, Romagnoli M, Corbetta L, Casoni $\mathrm{G}$, Busljetic K, Turato $\mathrm{G}$ et al. Differences in airway inflammation in patients with fixed airflow obstruction due to asthma or chronic obstructive lung disease. Am J Respir Crit Care Med, 167: 418-424, 2003.

6- Global Initiative For Chronic Obstructive Lung Disease (GOLD) 4: 24-30, 2008.

7- Ross R. Atherosclerosis - an inflammatory disease. N Engl J Med, 340:115-126, 1999.

8- Torres JP et al. C-reactive protein levels and clinically important predictive outcomes in stable COPD patients. Eur Respir J, 27: 902-907, 2006.

9- Torres JP, Pinto-Plata V, Casanova C, Mullerova H, Cordoba-Lanus E, Muros de Fuentes $\mathrm{M}$ et al. C-reactive protein levels and survival in patients with moderate to very severe COPD. Chest, 133:1336-1343, 2008;.

10- Fogarty AW, Jones S, Britton JR, Lewis SA, McKeever TM. Systemic inflammation and decline in lung function in a general population: a prospective study. Thorax, 62:515-520, 2007.

11- Gökırmak M. KOAH'da Oksijen Tedavisi [Oxygen therapy in COPD]. Saryal S.B, Acican T. Kronik Obstrüktif Akciger Hastalıg1 [Chronic Obstructive Pulmonary Disease], 179-189, 2003.

12- Gök H. Klinik Kardiyoloji 1.Bask1 [Clinical Cardiology 1st Edition] Nobel Kitabevi, İstanbul, 97-171, 1996.

13- Salonen R, Salonen JT. Progression of carotid atherosclerosis and its determinants: a populationbased US study. Atherosclerosis, 81: 33-40, 1990.

14- Veller MG, Fisher CM, Nicolaides AN, Renton S, Geroulakos G, Stafford NJ, et al. Measurement of the ultrasonic intimamedia complex thickness in normal subjects. J Vasc Surg, 17: 719-725, 1993.

15- Gavin C. Donaldson, Terence A. R. Seemungal, Irem S. Airway and systemic inflammation and decline in lung function in patients with COPD. Chest, 128:1995-2004, 2005.

16- Kenji Minoguchi, Takuya Yokoe, Toshiyuki Tazaki. Increased carotid intima-media thickness and serum inflammatory markers in obstructive sleep apnea. Am. J Respir. crit. Care Med 172: 625-630, 2005.
17- O'Leary DH, Polak SF, Kronmal RA, Manolio TA, Burke GL, Wolfson SK. Carotid artery intima and media thickness as a risk factor for myocardial infarction and stroke in older adults. New Engl J Med, 340:14-22, 1999.

18- Geroulakos G, O'Gorman D, Nicolaides A ve ark. Carotid intima-media thickness: correlation with the British regional heart study risk score. $\mathrm{J}$ Intern Med, 235:431-433, 1994.

19- Iwamoto H, Yokoyama A, Kitahara Y, Ishikawa N, Haruta Y, Yamane K, et al. Airflow limitation in smokers is associated with subclinical atherosclerosis. Am J Respir Crit Care Med, 179: 35-40, 2009.

20- Ma SM, Wei CK, Liang CC, Chou MJ, Lee SY. The age correlation of the carotid intimamedia thickness according to sex and side in asymptomatic subjects acta neurol, Taiwan, 20:29-34, 2011.

21- Tosetto A, Prati P, Baracchini C, Manara R, Rodeghiero F. Age-adjusted reference limits for carotid intima-media thickness as better indicator of vascular risk: population-based estimates from the VITA project. J Thromb Haemost, 3: 122430, 2005.

22-Youn YJ, Lee NS, Kim JY, Lee JW, Sung JK, Ahn SG, et al. Normative values and correlates of mean common carotid intima-media thickness in the Korean rural middle-aged population: the Atherosclerosis RIsk of Rural Areas in Korea General Population (ARIRANG) study. J Korean Med Sci, 26: 365-71, 2011.

23- Ridker PM, Rifai N, Rose LL, Buring JE, Cook NR. Comparison of $\mathrm{C}$ reactive protein and low-density lipoprotein cholesterol levels in the prediction of first cardiovascular events. N Engl $\mathbf{J}$ Med, 347:1557-1565, 2002.

24- Sin Don D, Man SF. Why are patients with chronic obstructive pulmonary disease at increased risk of cardiovascular diseases? Circulation, 107:1514-9, 2003.

25- Kim SJ, Yoon DW, Lee EJ, Hur GY, Jung $\mathrm{KH}$, Lee SY, et al. Carotid atherosclerosis in patients with untreated chronic obstructive pulmonary disease. Int $\mathbf{J}$ Tuberc Lung Dis, 15: 1265-70, 2011.

26- Thorleifsson SJ, Margretardottir OB, Gudmundsson G, Olafsson I, Benediktsdottir B, Janson C, Buist AS, Gislason T. Chronic airflow obstruction and markers of systemic inflammation: Results from the BOLD study in Iceland. Respiratory Med, 103:1548-53, 2009. 